\title{
First Report of Web Blight of Rosemary (Rosmarinus officinalis) Caused by Rhizoctonia solani AG-1-IB in Korea
}

\author{
Md. Aktaruzzaman, Joon-Young Kim, Tania Afroz and Byung-Sup Kim* \\ Department of Plant Science, Gangneung-Wonju National University, Gangneung 210-702, Korea
}

\begin{abstract}
Herein, we report the first occurrence of web blight of rosemary caused by Rhizoctonia solani AG-1-IB in Gangneung, Gangwon Province, Korea, in August 2014. The leaf tissues of infected rosemary plants were blighted and white mycelial growth was seen on the stems. The fungus was isolated from diseased leaf tissue and cultured on potato dextrose agar for identification. The young hyphae had acute angular branching near the distal septum of the multinucleate cells and mature hyphal branches formed at an approximately $90^{\circ}$ angle. This is morphologically identical to $R$. solani AG-1-IB, as per previous reports. rDNA-ITS sequences of the fungus were homologous to those of R. solani AG-1-IB isolates in the GenBank database with a similarity percentage of $99 \%$, thereby confirming the identity of the causative agent of the disease. Pathogenicity of the fungus in rosemary plants was also confirmed by Koch's postulates.
\end{abstract}

Keywords Pathogenicity, Rhizoctonia solani, Rosemary, Rosmarinus officinalis, Web blight

Rosemary (Rosmarinus officinalis L.), an evergreen, woody, perennial herb, belongs to the mint family Lamiaceae that originated from the Mediterranean region. Nowadays, it is grown in different parts of the world, including Asia, Europe, and America. The species name is derived from the Latin word ros (dew) and marinus (sea) which means "dew of the sea." Rosemary is used fresh or dried; its essential oils are used as well. It contains significant quantities of essential oil, which is largely used as an ingredient of antibacterial, antifungal, and anticancer drugs in traditional medicine (as a digestive, tonic, astringent, diuretic and diaphoretic component, etc.), perfumery, and for preparing pulmonary antiseptics [1].

Rhizoctonia solani Kühn [teleomorph: Thanatephorus cucumeris (Frank) Donk] is a destructive soil-borne fungal

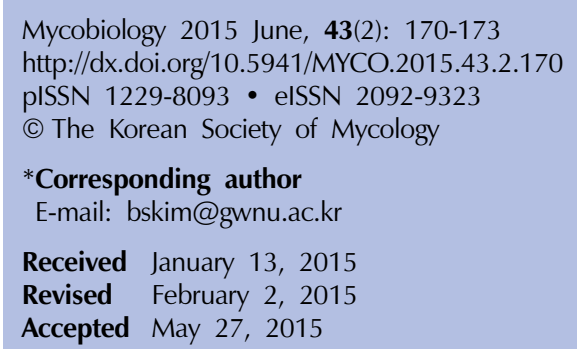

(a) This is an Open Access article distributed under the terms of the Creative Commons Attribution Non-Commercial License (http:// creativecommons.org/licenses/by-nc/3.0/) which permits unrestricted non-commercial use, distribution, and reproduction in any medium, provided the original work is properly cited. pathogen with a worldwide distribution. Many experts have estimated that this fungus can infect over 142 different species of plants [2]. Throughout Korea, at least 100 plant species have been reported as R. solani hosts [3]. This fungus has been divided into 12 anastomosis groups (AGs) according to hyphal anastomosis conduct, mycological characteristics, host range, pathogenicity, and other features [4]. Furthermore, AG-1 has been subdivided into three subgroups designated as AG-1-IA, AG-1-IB, and AG-1-IC [5]. R. solani AG-1 IB is a widely distributed fungus and causes great harm to many plants. The common symptoms of disease caused by this fungus are sheath blight, leaf blight, web blight, damping-off, root rot, head rot, and bottom rot [6,7]. The fungus was reported to cause web blight of rosemary in USA and Italy [8,9], but has not been reported in Korea so far. The aim of this research was to identify the causative agent of the web blight disease observed in rosemary in Korea, based on mycological characteristics, molecular phylogenetics, as well as pathogenicity.

Fungal isolation and pathogenicity test. In August 2014, web blight symptoms were observed on rosemary in Sachunmun, Gangneung, Gangwon Province, Korea (Fig. 1A). Specifically, the leaf tissues were blighted and white mycelial growth was seen on the stems. Diseased plants were collected in sterilized plastic polythene bags and sent to the laboratory for pathogen isolation. Infected plant parts were cut into small pieces measuring about 1.0 1.5 $\mathrm{cm}$, surface sterilized with $0.1 \%$ sodium hypochlorite $(\mathrm{NaOCl})$ for $1 \mathrm{~min}$, washed thrice with distilled water, and 


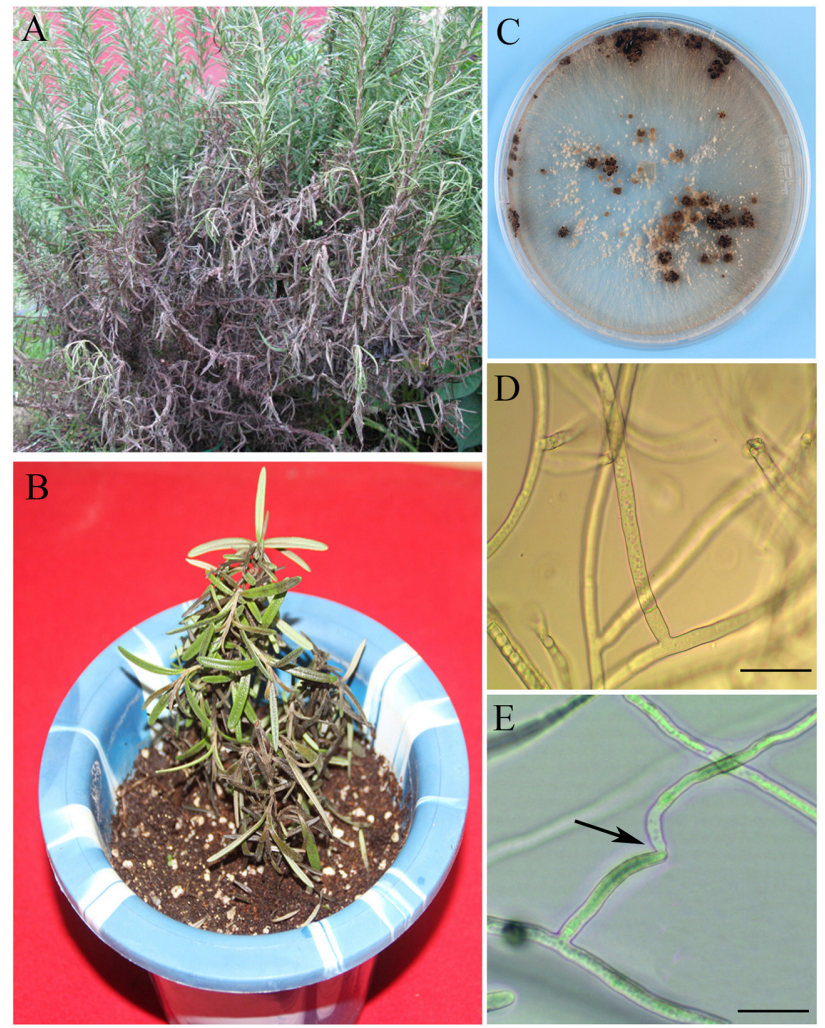

Fig. 1. A, Diseased rosemary plant showing web blight symptoms on leaves; B, Rosemary plants inoculated with Rhizoctonia solani developed web blight symptoms after 14 days of incubation; C, Two-wk-old colony and dark brown sclerotia of $R$. solani growing on potato dextrose agar medium; $\mathrm{D}$, Mycelia showing branching at a $90^{\circ}$ angle.; E, Occurrence of anastomosis (hyphal fusion) (scale bars: $\mathrm{D}, \mathrm{E}=40 \mu \mathrm{m}$ ).

dried with a sterilized filter paper. The small pieces were then placed in Petri plates containing potato dextrose agar (PDA) medium (Difco, Detroit, MI, USA) and incubated at $20 \pm 2^{\circ} \mathrm{C}$ for 5 days. To obtain a genetically pure culture, the hyphal tips from the mycelia grown on the PDA plates were cut and transferred to fresh PDA plates.

For the pathogenicity test, three fungal mycelial discs (14-day-old, $6.5 \mathrm{~mm}$ in diameter) were placed on the stems of three young plants (65-day-old) on the soil line and covered with plastic bags. Three other plants served as controls where only agar plugs were used. All the plants were then incubated in a growth chamber (at $28 \pm 2^{\circ} \mathrm{C}$, $90 \%$ relative humidity). After 14 days, blight symptoms similar to the original symptoms were seen on inoculated plants leaves, whereas no symptoms were observed in control plants. The pathogenicity test was performed twice. The fungal pathogen was re-isolated from disease lesions of inoculated plants. The re-isolated pathogen met the criteria stipulated by Koch's postulates and exhibited the same morphological characteristics as those seen in the original isolates (Fig. 1B). Subsequent to the fungal pathogen satisfying the criteria stipulated by Koch's postulates, it was recognized as the causal pathogen of web blight of rosemary.

Identification of the AG. Identification of the AG of the $R$. solani isolate was carried out on sterilized glass slides that were coated with $2 \%$ water agar medium and placed in Petri dishes. The mycelia of an AG tester and an isolate were placed on the two ends of a slide [10]. After $72 \mathrm{hr}$ of incubation at $20 \pm 2^{\circ} \mathrm{C}$, hyphal interactions were observed under an optical microscope $(\times 20$, Olympus $\mathrm{BH}-$ 2; Olympus, Tokyo, Japan) and the occurrence of anastomosis was established when hyphae fused with each other and exchanged cytoplasm. Tester isolates for AG-1-IA (KACC 40101), AG-1-IB (KACC 40108), and AG-1-IC (KACC 40117) were obtained from Korean Agricultural Culture Collection (KACC), and the identification of AGs was performed twice.

DNA extraction, PCR, and sequence analysis for molecular identification. DNA was extracted from fungal mycelium by using the cetyltrimethylammonium bromide method [11]. The primers ITS1 (5'-TCCGTAGGTGAACCTGCGC-3) and ITS4 (5'-TCCTCCGCTTATTGATATGC3 ) were used to amplify the internal transcribed spacer (ITS) and 5.8S rDNA regions [12]. PCR was performed in a total volume of $25 \mu \mathrm{L}$ by using $0.5 \mu \mathrm{L}$ of dNTP, 2.5 units of Taq DNA polymerase $(0.5 \mu \mathrm{L}$ of $5 \mathrm{U} / \mu \mathrm{L}$ enzyme; Bioneer, Daejeon, Korea), $2.0 \mu \mathrm{L}$ of genomic DNA, $2.5 \mu \mathrm{L}$ of $10 \times$ PCR reaction buffer and $5 \mathrm{pmol} / \mathrm{L}$ of each primer $(0.5 \mu \mathrm{L}$ each). The PCR amplification conditions were as follows: $94^{\circ} \mathrm{C}$ for $5 \mathrm{~min}$, followed by $35 \mathrm{cycles}$ of $94^{\circ} \mathrm{C}$ for $35 \mathrm{sec}$, $52^{\circ} \mathrm{C}$ for $55 \mathrm{sec}$, and $72^{\circ} \mathrm{C}$ for $1 \mathrm{~min}$, with a final extension step at $72^{\circ} \mathrm{C}$ for $10 \mathrm{~min}$. The sequence of ITS-5.8S rDNA was compared with the sequences in the NCBI database (http://www.ncbi.nlm.nih.gov/BLAST). MEGA5 program with the neighbor-joining method was used for phylogenetic analysis of $R$. solani [13].

Identification and characterization of $\boldsymbol{R}$. solani. Five fungal isolates were obtained from the web blight of rosemary. Since all isolates looked morphologically alike, only one isolate, namely RWB-3, was examined for identification. Isolate RWB-3 was identified as $R$. solani AG-1-IB by analyzing the morphological features of the isolated fungus and by carrying out rDNA sequence analysis. We found that the colony growth rate for the isolated fungus in PDA ranged from 25.7 to $28.6 \mathrm{~mm} /$ day. The fungus produced a white mycelium when young, but produced a brown mycelium with dark brown sclerotia after growing on PDA at $20 \pm 2^{\circ} \mathrm{C}$ for 14 days (Fig. 1C). The hyphae were often branched at a $90^{\circ}$ angle (Fig. 1D). Diameter of the hyphae ranged from approximately $2.6 \mu \mathrm{m}$ to $8.4 \mu \mathrm{m}$. The isolate anastomized only with the tester strain AG-1-IB (Fig. 1E). Morphological characteristics of the studied isolate are summarized in Table 1. The ITS arrangement was compared to the sequences in GenBank database by utilizing the NCBI BLAST tool. The 718-bp rDNA-ITS arrangement 
Table 1. Comparison of mycological characteristics of the pathogen isolated from disease lesions of rosemary with previously described characteristics of Rhizoctonia solani

\begin{tabular}{lll}
\hline \hline Characteristics & Studied isolate & R. solani ${ }^{\text {a }}$ \\
\hline Mycelium & White, later turning brown & Light brown \\
& Branched at $90^{\circ}$ angles & Often branched at $90^{\circ}$ angles \\
& Mostly multinucleate & More than two nuclei \\
Diameter of hyphae $(\mu \mathrm{m})$ & $2.6 \sim 8.4$ & $3 \sim 17.0$ \\
Sclerotium & Small, irregular & Small, irregular \\
& $0.4 \sim 1.6 \mathrm{~mm}$ & $1.0 \sim 3.0$ mm \\
& Dark brown & Dark brown to black \\
\hline
\end{tabular}

${ }^{a}$ Described by Parmeter [14].

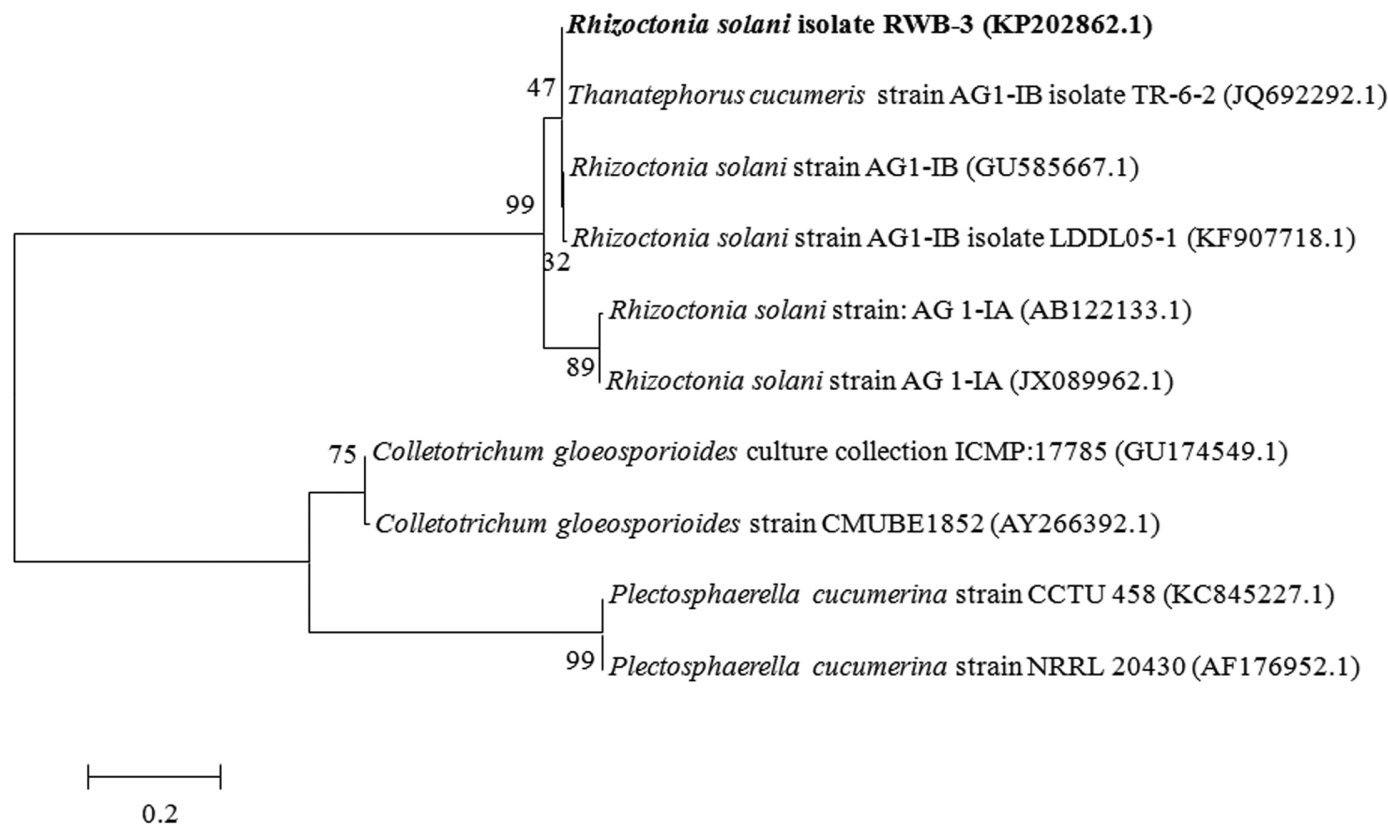

Fig. 2. Neighbor-joining phylogenetic tree of Rhizoctonia solani isolate RWB-3 and related species identified by the internal transcribed spacer gene sequences from the GenBank database. Numbers at the nodes indicate bootstrap values from a test of 1,000 replicates. The scale bar indicates the number of nucleotide substitutions. Evolutionary analyses were conducted using the MEGA5 program [13].

showed $99 \%$ similarity to sequences from some R. solani AG-1-IB (teleomorph T. cucumeris) species (accession Nos. JQ692292.1, GU585667.1, and KF907718.1). The nucleotide sequence of rDNA-ITS from the isolate has been assigned GenBank Accession No. KP202862. Thus, R. solani AG-1IB was identified as the causative agent of web blight of rosemary in Korea (Fig. 2). To the best of our knowledge, this is the first report of web blight of rosemary in Korea.

\section{REFERENCES}

1. Bozin B, Mimica-Dukic N, Samojlik I, Jovin E. Antimicrobial and antioxidant properties of rosemary and sage (Rosmarinus officinalis L. and Salvia officinalis L., Lamiaceae) essential oils. J Agric Food Chem 2007;55:7879-85.

2. Ogoshi A. The genus Rhizoctonia. In: Sneh B, Jabaji-Hare S, Neate S, Dijst G, editors. Rhizoctonia species: taxonomy, molecular biology, ecology, pathology and disease control.
Dordrecht: Kluwer Academic Publishers; 1996. p. 1-9. 3. Korean Society of Plant Pathology. List of plant diseases in Korea. 5th ed. Seoul: Korean Society of Plant Pathology; 2009. p. 7-766.

4. Ogoshi A. Ecology and pathogenicity of anastomosis and intraspecific groups of Rhizoctonia solani Kühn. Annu Rev Phytopathol 1987;25:125-43.

5. Snech B, Burpee L, Ogoshi A. Identification of Rhizoctonia species. St. Paul: APS Press; 1991.

6. Duan C, Yang G, Ni Z, Liu G, Wu H. Occurrence of foliar rot of Chinese cabbage, mint and lettuce caused by Rhizoctonia solani AG-1 IB in China. J Yunnan Agric Univ 2008;23:422-5.

7. Yang GH, Chen HR, Naito S, Wu JY, He XH, Duan CF. Occurrence of foilar rot of pak choy and Chinese mustard caused by Rhizoctonia solani AG1-IB in China. J Gen Plant Pathol 2005;71:377-9.

8. Holcomb GE. Web blight of rosemary caused by Rhizoctonia solani AG-1. Plant Dis 1992;79:859-60. 
9. Garibaldi A, Bertetti D, Pensa P, Poli A, Gullino ML. First report of web blight on rosemary (Rosmarinus officinalis) caused by Rhizoctonia solani AG-1-IA in Italy. Plant Dis 2013;97:844-5.

10. Parmeter JR, Sherwood RT, Platt WD. Anastomosis grouping among isolates of Thanatephorus cucumeris. Phytopathology 1969;59:1270-8.

11. Möller EM, Bahnweg G, Sandermann H, Geiger HH. A simple and efficient protocol for isolation of high molecular weight DNA from filamentous fungi, fruit bodies, and infected plant tissues. Nucleic Acids Res 1992;20:6115-6.
12. White TJ, Bruns T, Lee S, Taylor J. Amplification and direct sequencing of fungal ribosomal RNA genes for phylogenetics. In: Innis MA, Gelfand DH, Sninsky JJ, White TJ, editors. PCR protocols: a guide to methods and applications. San Diego: Academic Press; 1990. p. 315-22.

13. Tamura K, Peterson D, Peterson N, Stecher G, Nei M, Kumar S. MEGA5: molecular evolutionary genetics analysis using maximum likelihood, evolutionary distance, and maximum parsimony methods. Mol Biol Evol 2011;28:2731-9.

14. Parmeter JR. Rhizoctonia solani biology and pathology. Berkeley: University of California Press; 1970. p. 7-19. 